\title{
ALBANIAN FOREIGN POLICY IN THE POST-COMMUNIST ERA
}

\author{
Asst. Prof. Dr. Abdurrahim F. Aydın and Erjada Progonati \\ Inonu University in Malatya and Gazi University, Ankara
}

\begin{abstract}
:
Being under the totalitarian regime during the communist period, Albanian foreign policy sacrificed its political objectives and national interests. With the collapse of communism, Albanian leadership has the foremost task to assess correctly the real objectives and the genuine interests of Albanians in Albania, Serbia, Kosovo, FYROM, Montenegro and Greece. The aims in this article are to emphasise today's (post-communist) Albanian foreign policy and to show what is lacking in Albanian foreign policy in order to fulfill its national interests in its continuous efforts to establish a successful europeanization and democratization of culture.
\end{abstract}

Keywords: post-communism, foreign policy, national interest, Balkans, minority.

\section{Resumen:}

Al encontrarse bajo un regimen totalitario durante el periodo comunista, la política exterior albanesa sacrificó sus objetivos políticos y sus intereses nacionales. Con el colapso del Comunismo, el liderazgo albanés tiene la encomiable tarea de evaluar correctamente los objetivos reales y los intereses genuinos de los albaneses en Albania, Serbia, Kosovo, KYROM, Montenegro y Grecia. Los propósitos de este artículo son emfatizar la politica exterior albanesa actual (post-comunista) y mostar qué falta en la política exterior de Albania para satisfacer sus intereses nacionales en sus continuos esfuerzos para establecer una exitosa europeización y democratización de su cultura.

Palabras clave: post-comunismo, política exterior, interés nacional, Balcanes, minorías.

Copyright (C) UNISCI, 2011.

Las opiniones expresadas en estos artículos son propias de sus autores, y no reflejan necesariamente la opinion de UNISCI. The views expressed in these articles are those of the authors, and do not necessarily reflect the views of UNISCI.

\footnotetext{
${ }^{1}$ Abdurrahim F. Aydin is Assistant Professor at Inonu University in Malatya, Turkey.

${ }^{2}$ Erjada Progonati is PhD student at Gazi University in Ankara. Email: adaprog10@yahoo.it
} 


\section{Introduction}

Territorial bounderies are one of the most important factors in international relations for a country because it is one of the permanent elements beside a nation's culture, history and population. Greater attention is often given to the economy, technology and military capacity. As a result of all the above factors, countries use politics like capable actors in international area. A century of shifting borders has left ethnic Albanians scattered across Kosovo, Serbia, Montenegro, Macedonia, and Greece. Due to its strategic geo-political position, Albania, is seen as an interesting and different country of the Balkans. This is firstly because of its continuous efforts to achieve unity among its population divided by three different religions, two separate dialects and also a path of history full of typical Balcan conflicts. In the late $80 \mathrm{~s}$, the dramatic political changes in East European countries and also in Albania attracted the world's public attention towards the Balkans. These conflicts that originated in the Balkan Peninsula jeopardized the steps taken by European Union (EU) for its further enlargement. Besides the Albania's strategic position, the second important factor that made Albania vital was its religious diversity. Although the majority of the people are Muslims, there is also a part of population that belongs to the Catholic and Orthodox Christian religion. This mix in religion has created the colourful diversity. Albania's international relations are well balanced. While maintaining a cordial relationship with NATO and EU, Albania has also succeeded in developing good relations with Moscow and the Islamic countries. In other words, with the collapse of the communist era, Albania begun a new era, in her foreign policy. After a long isolationist policy, Albanian government tried to create a democratic society and establish bilateral/multilateral relations with the other countries and international organizations. Due to its geographical position as a Balcanic country, Albania is trying to shape her policy by harmonising the different nationalisms that have became stronger in the peninsula by preserving the varity of cultures and religions while intensifying efforts in becoming a EU member. After the Albanian integration to NATO, the integration to the EU is not only a political necessity, but also a moral duty that follows the whole of Albania's national interest.

The problems in the Balkans are various but the most crucial one is the different ethnicities. In this respect, Balkan countries must first and foremost ensure their own regional security without the intervention of the international community. One of our aims in this article is to define what is being done doing in this regard? Balkan security has been sustained with the increasing cooperation between Europe and USA. This co-operation should slowly come to an end with the Balkan countries cooperation and the withdrawal of the present foreign military forces from the region. Because of the vacuum that will be created, the Balkan countries' institutions will be engaged with their own security themselves.

Comparing the other Balkan countries, it seems harder for Albania to make progress easily in all these processes because of her past sui generis communist (isolationist) regime. But at the same time Albania is blessed with the system of a non-expansionist state. The Albanians struggle is focused on worthwhile goals like national freedom, self-governance and stability. The Albanian foreign policy revolves around strengthening the position in Southestern Europe and the Southern Balkans by putting up great efforts in fostering democracy, prosperity and peace of the region. As a result, the foreign policy certainly promotes integration across national borders; integration to the West and long-lasting political and economic measures for Albanians inside and outside the Republic of Albania (Kosovo, Former Yugoslavia Republic of Macedonia (FYROM), Greece, Montenegro). Albania's European integration goes through a parallel process of regional integration. Tirana is 
concerned with increasing the pace of development and the integration among the region's countries. The result of this is the expansion of the area and the prevalence of democratic Euro-Atlantic standards and institutions as well as the chances for conventional borders in an effort to guarantee the freest possible movement of citizens, goods, capitals, ideas and cultures. However this goodwill offers no guarantees of success. It is up to Albanian leaders to change todays possibilities into national interest.

\section{National Interest and Foreign Policy}

The beginning of the twentieth century witnessed the denunciation of national interest. Indignation at the moral deficiencies of the very balance of power drove President Woodrow Wilson toward the general postulate of a New World "safe for democracy" where the national interest would disappear. But the events of the two world wars impressed a number of analysts with the thought that the global conflict might have been avoided. ${ }^{3}$ They turned to the national interest as a concept which could be used to "describe, explain and access the foreign policies of nations." 4 There is a consensus that the foreign policy of leading Western powers cannot be understood through considering nation states as egoistic actors pursing narrow selfinterest. The inability to establish a shared socio-political vision of what 'the nation' stands for and the lack of a strong "idea of the state" in Buzanian terms has meant that Western powers find it difficult to formulate a clear foreign policy or to legitimise the projection of power abroad in terms of national interest. ${ }^{5}$ The concept of "the national interest" is an ever present feature of contemporary diplomatic discourse and has been widely analysed by historians and political scientists. Meanwhile, realists traditionally, and constructivists more recently, claim that "the national interest" is a key explanatory tool in the analysis and understanding of contemporary foreign policy. Foreign policy can be a powerful mechanism for generating a sense of national identity, of shared political purpose and mission. Rather than "modern" politics where the state had a political programme or project which promised to transcend the present, to take society forward, today's governments are caught in a "postmodern" malaise. There appears to be no vision or project which can give government a sense of mission or purpose. Governments are increasingly seen to be less important or influential. In this view, historically Albania sacrificed its national interest for the sake of such notions as world communism, norms of international behaviour and the belief that the support of many states is essential to Albania's solutions. This will be clearer by explaining the factors that affect Albanian foreign policy.

\section{The Internal Factors That Affect Albanian Foreign Policy}

\subsection{The Minorities Within Albania}

Nationality formed the basis of a political Project in such as constructing a state. The shaping of different national identities in the Balkans brought with it a lot of political disputes. On the level of contemporary politics this has meant that the nationalist ambitions of all ruling elites

\footnotetext{
${ }^{3}$ De Tocqueville, Alexis (1961): Democracy in America, New York, TFNI.

${ }^{4}$ Morgenthau, Hans J. (1951): In Defence of the National Interest, New York, University Press of America.

${ }^{5}$ Shembliku, Rozeta E. ( 2004): The National Interest Tradition and the Foreign Policy of Albania, Master of Arts Thesis, Tufts University.
} 
in the region have inevitably been in conflict. Conflicting historical arguments could be (and were) easily converted into political ones, and those into military ones.

There are three ethnic minorities in Albania, Greek, Slav-Macedonian and Montenegrin minorities and two cultural minorities, Wallachian and Roma. The Greek minority is the most important minority of the all minority groups. The rights of minorities are guaranteed by the constitution of 1998 in Albania. According to this constitution, the minorities in Albania are equal in social, economic, poitical and civil right standards with those of the Albanians. Albania signed the "Convention for the Protection of National Minorities" of the Council of Europe which entered in force on January 1, 2001. ${ }^{6}$

There are several conflicts between Greece and Albania. The main cause of these conflicts in the bilateral relations of Albania and Greece is the welfare of the minority living in the south of Albania and the Albanian refugees who emigrated to Greece. With regard to the Greek "Northen Epirus" plan, Albania approaches with skepticism to the Greek minority living in the southern Albania. ${ }^{7}$

In 1986, the crossing of borders was legalized between the two countries. ${ }^{8}$ In 1987 , Greece abated the 1940's declaration of war, expecting for a positive impact to the Greek minority in Albania. Unfortunately, Greek Parliament did not win the majority vote for the removal of the Status of the Law of War. Then the relationships between the two countries began to deteriorate.

With the collapse of communism, the Albanian Parliament transited to a multi-party system. In February 1991, "Omonia" was established, a Greek party which gave priority to defending the rights of the Greek minority. In the March 1991 elections, "Omonia" put five of their members in the Albanian Parliament. ${ }^{9}$

In July 1993, Greek Prime Minister, Constantinos Mitsotakis, terminated the same rights that Kosovo's Albanians had for the Greek minority in Albania. The relations between Greece and Albania became more aggravated. At the same time, when the "Omonia" leaders demanded autonomy of the Greek minority in Albania, the Albanian President at that time, Sali Berisha, adopted a less tolerant policy against the Greek minority. In 1994, the five elected members of "Omonia" were arrested and charged for promoting separatism. In response, the Greek government attacked the Albanian refugees again by deporting approximately seventy thousands of. ${ }^{10}$ At the same time Greece threated that they would use their veto right to stop the aid being given to Albania from EU. ${ }^{11}$

In 1995, amnesty was granted to Omonia's leaders and the relations between Greece and Albania started to improve again. At that time, the Greek Foreign Minister, Korolios Papulias, visited Tirana. In 1996, Greek President, Costis Stephanopoulos, also visited

\footnotetext{
${ }^{6}$ Albania 2008 Progress Report (2008), at http://eeas.europa.eu/delegations/albania/documents/eu_albania/2008_progress_report_en.pdf

${ }^{7}$ Hatipoğlu, M. Murat (1999): Yunanistan'da Etnik Gruplar ve Azınlıklar, Ankara, SAEMK.

8 Türbedar, Erhan: "Tedirginlikten Dostluğa: Yunanistan-Arnavutluk İlişkileri”, Stratejik Analiz, no 91 (November 2007), pp. 47-65.

${ }^{9}$ Veremis, Thanos (1995), Greece's Balkan Enlargement, Athens, ELIAMEP.

${ }^{10}$ Duffy, Terence: "Albania: Beyonce The Hoxha Legacy", in Kostecki, Wojciech; Zukrowska, Katarzyna and Goralczy, Bogdan (eds.) (2001):Transformations of Post-Communsit States, Londra, Macmillan Press LTD, pp. 80 .

${ }^{11}$ Lani, Remzi; Schmidt, Fabian: “Albanian Foreign Policy Between Geography and History”, The International Spectator, vol. 33, n², (April-June 1998), pp. 63.
} 
Albania. It was the first time that a Grek president visited Albania. During this visit the two countries signed the Treaty of Friendship and Cooperation. ${ }^{12}$

Up until 1996, the Greek government feared neighboring countries would implement the economic embargo on Macedonia and vetoed the funds that EU allocated to the neighboring countries of Greece. In 1996, the Albanian-Greek relations began to change. It was at this time that Albanian government moved to establish good relations with neighbouring countries. Tirana started to develop a good relationship with the Republic of Turkey. Turkey then began fostering good relations towards the whole of the Balkans. It is also noteworthy to mention that in 1991 when FYROM became independent Greek government didn't recognize it. Consequently, the new state of FYROM established closer bilateral relations with the Republic of Turkey.

After the elections held in 1997, the Socialist Party (rival to the Democratic Party)came to power. Albanian-Greece relations became even closer during this period. This was related to the economic problems that Albania had in this period. The number of Albanians that emigrated to Greece increased rapidly. Greece included Albania to the The Greek Plan for Economic Re-Structuring of the Balkans (HIPERB). Greece also undertook the financing of certain infrastructure projects in Albania. In January 2006, the Greek government offered an aid to the tune of 184 million Euros to Albania. Due to the fact that Greece can prevent these funds and can also veto the Albania's membership process to EU, the Albanian Government's is trying to maintain good relations with Greece. ${ }^{13}$

Throughout different periods of history it has been obvious that Greece tended to be an allied power in the Balkans. Despite today's economic problems, Greece generally improves and strengthens the "economic diplomacy" that applies to the Balkan states. But obviously, the Albanian government took some steps to correct the involvement of the Greek inside its borders. On November 2005, the report of the European Commission described the important progresses the Tirana regime has made in the protection of minorities rights. In January 2008, in a speech about the protection of the rights of the Greek minorities in Albania, the Greek President Karolos Papulias, explained that everyone of Greek origin could turn to Greece to obtain a dual citizenship. Berisha reciprocated in a similar gesture to Albanians in Athens. In this case some Albanian emigrants in Greece and changed their Albanian names to Greek names to take a Greek passaport. In this case, the Greek government's proposal for dual citizenship posed a danger to the identity of some of the Albanians that changed their real names. From then on, Greece has dealt closely with the Greek minority in Albania, although rejecting the existence of the Albanian minority within its borders since 1940s.

There is another minority group living in Albania called Vlah, which can also be reffered to as: Rumani, Arumani, Vlah, Kutsovlehos (Greek), Shepherd (Albanian), Tsintsar (Serbian), Karaguni (Turkish). They live in at least eight Southeastern European countries: Greece, Albania, Bulgristan, Macedonia, Serbia, Montenegro, Bosnia-Herzegovina, Croatia. They are not assimilated totally into these countries and the language they speak is from a Latin origin. It seems that Vlahs are Romanized Illyrians, Thracians, Greeks and Dacias.

There are still some unsolved historical mysteries about Vlahs. For example, today, the hometown of Vlahs is Pindus Mountains (northern Greece). But there is no evidence that

\footnotetext{
12 Türbedar, op. cit., pp. 70.

13 "Politika Ballkanike e Greqise Sot", Koha Jone, 15 February 2008.
} 
this region was occupied by Romania. There are 38 thousands Vlahs in Serbia, 35 thousands in Albania, 10 thousands in Bulgaria, 8 thousands in FYROM. ${ }^{14}$

Table 1: Albanian Ethnic Structure

\begin{tabular}{|l|l|}
\hline Nationality & The Rate of Total Population (\%) \\
\hline Albanian & 92,5 \\
\hline Gipsy & 2,5 \\
\hline Greek & 1,8 \\
\hline Macedonian & 0,4 \\
\hline Vlah & 0,1 \\
\hline Total Population & 3,5 million \\
\hline
\end{tabular}

Source: Halil Akman, Paylaşılamayan Balkanlar, IQ Kültür Sanat Yayıncılık, Istanbul, 2006, p. 152

\subsection{Religions In Albania}

In Albania, there are people who belong to different religions, most often being Muslim or Christian, and can even be in the same family. The prince of Albania, Skanderbeg, was born in an Orthodox family, but after he was brought to the Otoman palaces he became a Muslim of Bektashi sect, to be a Janissaires. After he returned to Albania he re-adopted the Orthodox religion and as the last will and testament after he died he was buried in the Catholic cathedral. Throughout Albanian history there has been no religious conflict.

Albanians adopted Islamic religion later than the other European countries. Muslims arrived to Albania before the Ottomans. Hiding behind the Orthodox religion, the Bektashi sect was brought for the first time in Albania. The easy adaption of Islam in Albanian society led to the emergence of the Bektashi sect and the Orthodox religion in Albania. Even if Islam was widespreaded in Albania, the Sharia has never been adopted as states law. Islam has played a major role in the political arena of Albania because it was the most important factor that differed Albanians from Serbs (Kosovo region) and Greeks (Chamurya region).

In 1929, King Zogo worked to limit the number of mosques. In an attempt to keep away the Islam religion from the state, he tried to keep closer relations between Albania and Western countries. In 1945, the Communist regime was focused especially against the Catholic Church. In this period, Catholics were viewed as agents that would harm the Albanian Government. ${ }^{15}$

After the collapse of the communist regime, Sali Berisha became the first Prsident of the democratic system in Albania. At that time the religious places were repaired and

\footnotetext{
${ }^{14}$ Doja, Albert (2001): Perdorimi Etik i Fese ne Rindertimin e Identiteve, Tirane, p. 85-87.

${ }^{15}$ Ibid., p. 90-94.
} 
Albanian Governement tried to develop relations with Islamic countries. Albania also became a member of the Organisation of Islamic Conference. However, the Government of Albania gave less attention to interest in religious (Islamic) affairs later.

In the 1990s, some Christian organizations in Albania were striving to Christianise the Muslim people. As a result, Western European countries and the United States brought new religious elements to Albania such as Jehovah's Witnesses, Adventists, Mormons, Christians, Presbiterians and all branches of Protestantism. However, with the Christian activities that involved mostly the Albanian neighboring countries like Greece and Italy. Christian organizations used different policies to change the religion of the Muslim people in Albania: trying to re-write the history books, spreading anti-Islamic discourses, enforcing the Albanians that were seeking permission to reside in Greece to change the religion from Islam to Orthodox. These organizations were sponsored by Catholic religious programs and institutions engaged in the propagation of the Christian culture. ${ }^{16}$ Albania is a country that always needed foreign aid (this will be explained also in The Economy Factor). The aid that the U.S. extended Albania was for humanitarian activities. But this money was mostly directed to fraudelent purposes. The Albanian government was supported by these groups. But the groups' primary objectives was to change people's religion to Christianity.

Despite the Enver Hoxha's anti-Islamic propaganda of pressure the people of Albania religious tolerance. Muslims and Christians live together amicably.

Table 2: Albania's Religious Structure

\begin{tabular}{|l|l|}
\hline Religion & The Rate of Total Population (\%) \\
\hline Muslim & 70 \\
\hline Orthodox & 20 \\
\hline Catholic & 10 \\
\hline
\end{tabular}

Source: Halil Akman, Paylaşılamayan Balkanlar, IQ Kültür Sanat Yayıncılık, Istanbul, 2006, p. 153

\subsection{Nationalism: Pan-Albanism Or "Greater Albania"}

Demographically Albanians are one of the most dispersed nations of the Balkans. Since 1913, the Albanian nation has been fragmented. Also, Albanians are spread throughout different Balkan countries (the number of Albanians in the Balkans is listed on Table 3). In this respect, especially after the Cold War, Albania drew attention from the international community. This is because, there is a widespread misunderstanding about Pan-Albanian national aspirations, which are seen by many as a serious threat to Balkan stability. ${ }^{17}$

\footnotetext{
${ }^{16}$ Alexandra Popovic (1995): Balkanlar'da İslam, Istanbul, İnsan Yayınları.

${ }^{17}$ Mandac1, Nafiz; Erdoğan, Birsen (2001): Balkanlar'da Azınlık Sorunu: Yunanistan, Arnavutluk, Makedonya ve Bulgaristan'daki Azınlıklara Bir Bakış, Stratejik Araştırmalar ve Etütler Milli Komitesi, Ankara.
} 
There is a rapid-spreading wave of nationalism within the Albanians living in Kosovo, Macedonia, Montenegro and Greece. In contrast to the aging and stagnant population of their Balkan neighbors, Albanians are a young and rapidly growing population. On the other hand Kosovo's independence process brought with it a few questions, such as: Is there any possibility for ethnic Albanians to live in a single country, or is the idea of "Greater Albania" still alive? These elements together bring further attention to the "Albanian Question". ${ }^{18}$ The entity called "Greater Albania" including Ulcinj, Northern Kosovo, Preveza, Struga and Preshova Valley. In the scenarios, after Kosovo declared its independence, it is expected that they will be united to Albania. This proposal will bring to light a new Albanian state with seven million people that will not only disintegrate the FYROM's territory but will also create a new power center that would undermine the balance in the Balkans.

However, this expectation seems to be impossible considering the status Albania has on the international stage and the other realities in the region as well. Even if the Albanian Government can manage to prove the formation's integrity, international actors will oppose it for the reason that today's Balkan countries' borders are limited according to international treaties and they couldn't be altered. Another reason that this formation could not become real (at least for now) is due to the better geo-strategic, economic, military and political situation that Greece and Serbia have towards Albania. ${ }^{19}$ Besides these two countries, Montenegro and Macedonia, that are newer neighbouring countries of Albania, have recently had a better international image when compared to Albania. Therefore, these countries have greater support in the international arena. In other words, looking at international influence, Albania does not have an advantageous position in the pursuit of a greater Albania. Consequently, today Albania cannot ensure the integration of its people because of this lack of influence and the poor economic and military infrastructure. Other than this fact, it does seem that the cultural, religious and historical differences which Albanians have will never allow them to live together under a common roof. ${ }^{20}$ Albanians are therefore more interested in developing cultural and economic ties with the other Albanian entities in the southern Balkans, while maintaining separate statehood. In a wiser move, successive Albanian governments have opted for a strategic partnership with Macedonia as both aspire toward membership in NATO and the European Union. The independence of Kosovo remains at the core of the Albanian national question. But each of the five Albanian entities in the Balkans has its own distinct problems and agendas to address. In conclusion, due to its multi-religious nature, Albania has no established common culture.

Table 3: The Population of Albanians in Balkans

\begin{tabular}{|l|l|l|}
\hline Balkan States & Total Population & $\begin{array}{l}\text { Rate of Total Population } \\
\mathbf{( \% )}\end{array}$ \\
\hline Albania & 3.500 .000 & 95,2 \\
\hline
\end{tabular}

\footnotetext{
${ }^{18}$ International Crisis Group, “Pan-Albanism: How Big a Threat to Balkan Stability?”, Europe Report, no 153 (25 February 2004), at http://unpan1.un.org/intradoc/groups/public/documents/untc/unpan014972.pdf 31.

${ }^{19}$ T., Ortakovski V.: "Greater Serbian, Greater Albanian Nationalism and Kosovo", Paper Presented at the Annual Meeting of the International Studies Associaotion 48th Annual Convetion, Hilton Chicago, IL, USA, at http://allacademic.com/meta/p178655_index.html.

${ }^{20}$ Yılmaz, Veli (1998): Siyasi Tarih, Istanbul, Harp Akademileri Basım Evi.
} 


\begin{tabular}{|l|l|l|}
\hline Kosovo & 2.200 .000 & 90 \\
\hline Serbia & 5.832 .000 & 0,8 \\
\hline FYROM & 1.991 .018 & 22,8 \\
\hline Montenegro & 633.000 & 6,5 \\
\hline Greece & 10.244 .000 & 0,9 \\
\hline
\end{tabular}

Source: Halil Akman, Paylaşılamayan Balkanlar, IQ Kültür Sanat Yayıncılık, İstanbul, 2006, p. 155

From time to time, the idea of acreating a Balkan League has been raised however, for different reasons this idea couldn't be realized. From an ethnic standpoint, Albania has the possibility to merge within the EU umbrella. Within supranational EU, Albania is likely to be ethnicaly, geographicaly, economicaly and politically united within the boundaries of EU. ${ }^{21}$

If Albania becomes an EU member, it will support the Albanian minorities that live in other countries. In theory, it is logical that Albanian minority problem be solved after Albanian EU membership, but in practice there are some EU member countries with similar problems with their minorities which the EU could not resolve. For example, the case between Great Britain and Ireland. Although both of them are EU members, they have not produced any solution about the Northern Ireland problem. Despite all of these, it must be empasized that Albania should not be outside of the EU's horizontal and vertical enlargements.

\subsection{The Economic Factor}

Albania's economy has improved substantially throughout recent years and has outperformed many other countries in the region. The restructurizing from a regulated to a free market economy was the cause of many problems in Albania. As the last of the central and eastern European countries to embark on democratic and free market reforms, Albania started from a disadvantaged position due to Hoxha's catastrophic economic policies. Inflation was enormous in the beginning and the country experienced rates of 50\% monthly. By the end of 1993, however, inflation stabilized at a rate of 3 to $4 \%$ per month. Despite the positive development, Albania is still considered one of the poorest countries in Europe. ${ }^{22}$

According to the Bank of Albania, per capita income was $\$ 4,070$ in 2009 , and was expected to reach $\$ 4,200$ in 2010. According to preliminary data by the World Bank's Poverty Assessment Program, 12.4\% of the population lived below the poverty line in 2008, marking a considerable improvement from $25.4 \%$ in 2002. This decline in poverty levels was mainly due to higher per capita GDP. Fiscal and monetary discipline has kept inflation

\footnotetext{
21 Alibali, Agron (1997): Mendime per Çeshtjen kombetare Shqiptare dhe Disa Probleme te se Drejtes Kombetare, Tirane.

${ }^{22}$ Albania. Political, Economical and Social Impacts onEnvironmental Protection at the Spring of 1994, at http://archive.rec.org/REC/Publications/StratIssues/FeeBased/Albania.htm.
} 
relatively low, averaging roughly $2.6 \%$ per year from 2006-2009. Although the average inflation rate was expected to reach $3.6 \%$ in 2010, that is still within the Central Bank target of 3 plus or minus $1 \%{ }^{23}$ According to official estimates, the unemployment rate as of September 2010 was $13.52 \%$. The Albanian economy was partially sheltered from the global financial crisis and the economic downturn, and the Albanian banking sector survived the global financial crisis with sufficient liquidity.

Albania is trying to attract direct foreign investment (DFI) and promote domestic investment. Increasing DFI is a top priority for the Albanian Government, especially in the light of the steady decrease of remittances. However, the collapse of the infamous pyramid schemes in 1997 and the instability that followed posed a tremendous setback. ${ }^{24}$

Tirana has put in place a liberal foreign investment scheme, and the government is working on bettering the business climate through fiscal and legislative reforms and infrastructural improvements. Albania continues to be an import-oriented economy and the EU remains Albania's main trading partner, providing $64.1 \%$ of Albania's imports and receiving $70.2 \%$ of the exports as of September $2010 .^{25}$ The first step of Albania towards the EU accession process was to sign the Stabilization and Association Agreement (SAA, 2006) with the European Union. In April 2009, Albania became a NATO member country and at the same time submitted its application for EU membership, both considered major milestones in the country's history and economy. Trade with Italy and Greece has, steadily declining since 2008 , and continues to represent the largest share of EU trade, with a combined $40.8 \%$ of imports and $56.4 \%$ of exports as of September $2010 .{ }^{26}$ Other major trading partners include Turkey, China, and Germany. The impact of CEFTA in Albania's trade with member countries has been small. Trade with the United States (total trade with U.S. is 3\%) continues to account for an insignificant part of Albania's trade volume, focusing on a narrow range of US goods and products.

\subsection{Political Forces in Albania}

As one of Europe's poorest countries, Albania is member of NATO but the European Union rejected its application last year to become an official candidate for the membership of the bloc, urging it to fight corruption and establish a functioning democracy and the rule of law. The long transition to democracy in Albania is ongoing and connected to the fact that the country has been isolated and underdeveloped for centuries. The western mentors have often turned a blind eye to meaningful and significant developments in the political arena and the democratic progress of Albania - while particularly urging for press freedom and the fight against corruption. Brussels hoped that by giving Albania the carrots of NATO membership and including it in the visa-free regime that the overall political climate would change for the better. But the situation in this territory is hoping to gain more substantial success.

There are two main political parties in Albania, the Socialist Party (SP) and the Democratic Party (DP). Until the 2009 elections, there was a period of relative stability and

\footnotetext{
${ }^{23}$ Albania, at http://www.state.gov/r/pa/ei/bgn/3235.htm.

${ }^{24}$ Albania, at http://www.state.gov/r/pa/ei/bgn/3235.htm.

${ }^{25}$ Albania, at http://www.state.gov/r/pa/ei/bgn/3235.htm.

26،Albania: China, Germany, Italy and Greece Are Main Trading Partners”, at http://www.balkans.com/opennews.php? uniquenumber $=88942$
} 
efforts on the part of Tirana to forge relations with the wider region. During the 2009 elections, DP and its leader, Sali Berisha, defeated SP which was headed byEdi Rama. After this, the government and the opposition could not set aside their differences over the elections. In the absence of developed state-institutions, it was hard to organize free and fair elections. In other words, elections have always fallen short of any real democratic process, and they tend to represent partisan agenda or battles between high-profile political figures who use the polls to stack the deck against their opponents and to forge lucrative relations with dubious, influential private figures. ${ }^{27}$

After several disagreements, Rama started to organize mass protests like the ones currently happening in the Middle East by getting his supporters on to the streets in larger numbers. These developments are essential in many ways. Firstly, EU member states are already hesitant on the further enlargements of the union. An earlier round of visa liberalization for Serbia, Montenegro and Macedonia produced grim results: large numbers of asylum seekers showed up at Europe's doorsteps and some EU member states almost balked at offering the same deal to Bosnia and Albania.

Secondly, this process is very important for Kosovo too because Albania is the main supporter of Kosovo in international arena. That's why for now Kosovo's authorities have to wait and see the developments in Albania.

Thirdly, the recent threats on January 21, 2011 have affected Albania's NATO membership. Albania joined the Alliance in April 2009, along with Croatia. Since 1992, when Albania began the NATO accession process, it has been viewed as a stabilizing factor. NATO could also rethink its membership roster in light of the violence where it concerns Bosnia's pending NATO membership. If the situation in Albania causes NATO to rethink its enlargement, Bosnia will be one of the first to suffer. ${ }^{28}$

\section{The External Factors In Albanian Foreign Policy}

\subsection{The Albanian Minorities in Balkans}

The boundaries within Albanians society are easily distinguished. The nation possesses different religious, cultural and languagistic characteristics from the other nationalities in the region. All ethnic Albanians in the Balkans are encircled by the Orthodox axis. In this view, Albanians that are living in the Balkan countries (FYROM, Greece, Montenegro) are minorities if this data is analyzed in proportion with the total population of these countries. Albanians in Kosovo are still considered a minority by Serbia (because it doesn't recognize Kosovo) even if the Albanian population is the majority ( $90 \%$ of the population). In the international application of law there isn't any clear definition of "minority" that is accepted in general by all states. All this is almost concerned with the fear the nation-states have towards the plausible damages that minorities can cause. In other words, the lack of a distinct definition of "minority" is due to nation-states' reservations in connecting themselves to a "legal" minority definition. The vague definition of minorities gives states the opportunity to

\footnotetext{
27 "Albania: The Wider Implications of a Political Crisis-Turned Violent”, at $\mathrm{http} / /$ www.isaintel.com/2011/02/07/albania-the-wider-implications-of-a-political-crisis-turned-violent 28 “Albania: The Wider Implications of a Political Crisis-Turned Violent”, http://www.isaintel.com/2011/02/07/albania-the-wider-implications-of-a-political-crisis-turned-violent/
} 
refuse minorities or minority status or the possibility to narrow interpretations for countries that are comprised of minorities. ${ }^{29}$

"Minority" is essentially a sociologic concept. ${ }^{30}$ Usually, there are two methods used in differentiating minorities from other communities:

a. Based on the numerical factor

b. The effect of minority rights on nation-states and the minority relations.

The most accepted method beside the numerical factor of minorities is the effection of their rights and obligations that they can use towards the majority. ${ }^{31}$ It is almost impossible to separate or demonstrate the nations like minority-majority. This was what happened in the case of Kosovo before the proclamation of independence on February 17, 2008. Numerically comparing other nations minorities to Kosovo's, Kosovars did not constitute a minority in the Former Yugoslavya. The number of the Albanians in Kosovo in the Former Yugoslavia was eight times more than the number of the official Montenegro Republic's population; two times more than the population of FYROM; more than Slovenia's population and the Muslim population that lived in Yugoslavya. ${ }^{32}$ The Albanians that live in Kosovo, constitute half of the number of Albanians living in Albania. In this case if half of the number of a nation is located in another country we can't call them minority regardless of the majority-minority report.

The "nation" is a socio-political concept, "race" is genetic concept and "national/ethnic group" is regarded as a cultural category. ${ }^{33}$ If a community is accepted as a nation, they should have the right of self- gorvernance. Otherwise, if a community is accepted as minority it should be recognized as an "individual" or "collective" entity and given their full rights. From this standpoint, according to former Yugoslavya's lawyers, the Albanians of Kosovo decent are a minority because they are a part of the Albanian nation and not of any other nation. In this case, Albanians have already used the self determination right established by the Republic of Albania. According to this, there can't be "installed" two Albanian states at the same time. This theory is also used against the Vojvodina population of Hungary. ${ }^{34}$ Belgrade's arguments in this vein are not fair. The theory of "a nation-a state" isn't written in any international law and there isn't any historical and diplomatical data that support this thesis. Take 20th century Germany for example that was divided into two countries. The Arap nation was divided into several countries. Korea is divided into North and South Korea. There are also several examples that legaly exclude the thesis of former Yugoslavya. ${ }^{35}$

Consequently, nation-states in disputes today require the recognition of their "individual rights" instead of "collective rights" for their social groups living within their boundarie given that "collective rights" recognition could be dangerous for their territorial integrity and the unity of their nation.

\footnotetext{
${ }^{29}$ Çavuşoğlu, Naz (2001): Uluslararası Insan Hakları Hukukunda Azınlık Hakları, Ankara, Su Yayınları.

${ }^{30}$ Terzioğlu, Süleyman Sırrı (2007): Uluslararası Hukukta Azınlıklar ve Anadilde Eğitim Hakkı, Ankara, Alp Yayınevi.

${ }^{31}$ Çelmeta, op. cit., p. 52-53.

32 Türbedar, Erhan (2006): Stratejik Öngörü: Balkanlar, Ankara, ASAM.

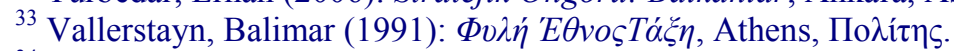

${ }^{34}$ Çelmeta, op . cit., p. 37

${ }^{35}$ Çelmeta, op. cit., p. 52-53.
} 
The uti possidetis is the principle that protects the independence of the new states and the territorial integrity and the peace between states. Usually the instability of the independence of some nations is determined by the fact that they are numerically smaller or they are located near the bounderies of the state. In the cases, the uti possidetis principle is applied. This is why in international relations law, Kosovo is one of the cases that could legaly be independent. The boundaries are not scattered territories and the population is not minority.

There is also an Albanian minority in the north-west of FYROM (from the southern Ohrid to Kumanova). In November 1968, Tetova's Albanians in FYROM began to demand unification with Kosovo, immediately after the Albanian demonstrations in Kosovo for an independent Repubic of Kosovo. This emergence of the establishment of such a republic was interpreted by Yugoslav Republic as the Albanian Republic's first step to reunification.

Most of the Albanians who live in Greece are Orthodox, but after the Second World War they began to live with the Muslim Albanians. The Albanians living in these regions are integrating into the Greek culture due to the Greek assimilation policy. As a result, the common language and education system under the Greek supervision made the assimilation policy easier and more peaceful.

\subsection{The Neighbouring Countries Policies}

Albania is bounded with Italy to the west, Macedonia to the east, Greece to the south, and with Montenegro and Kosovo to the north. The proximity of Albania to Italy has been a factor that in the post-Communist period made it easy for Albanian population to begin to emigrate in mass to Italy. ${ }^{36}$ Albanians, after emigrating to Italy experienced social and cultural change. They took on a new identity under the influence of Italy. ${ }^{37}$

Between 1951-1971, two million Southern Italians witnessed an internal migration towards the South. As a key country for both internal and external migrations, it has been a binary experience for Italy in terms of an intersection of national and international cultures. Nowadays there are almost 1,5 million foreigners living in Italy. In March of 1991, the "political migration" status of emigrants that came from Albania to Italy was replaced six months later by "economic migration". 38

In the 1990s, accusations of corruption and scandals in Italy led to the collapse of 45years political regime. The financial bankruptcy in Italy, the bad budget and the emphasis by the EU created a socio-economic shock. ${ }^{39}$ During this time, the Italian policy fought against illegal migration.

Albanians that emigrated to Italy have been settled into different social, cultural and political climate. Emigration in Italy is considered "an other format" and the stance of the EU against Italy is often referred like a moto "without Italy". Italy's national identity protection

\footnotetext{
${ }^{36}$ F., Debie: "Greece, Italy and Europe In the Face of The Albanian Problem”, in : Levy, J., (eds) (2001)., From Geopolitics to Global Politics, London/Portland, pp. 186-202.

${ }^{37}$ Russell, King; Mai, Nicola: "Myths and Mirrors: Interpretations of Albanian Migration to Italy", Studi Emigrazione, vol. 145, (2002), pp. 161-99.

${ }^{38}$ Mai, Nicola: "The Cultural Construction of Italy in Albania and Vica Versa: Migration Dynamics, Strategies of Resistance and Politics of Mutual Self-Definition Across Colonialism and Post-Colonialism", Modern Italy, vol. $8, \mathrm{n}^{\circ} 1$ (May 2003), pp. 77.

${ }^{39}$ Mai, Nicola; Schwander-Sievers, Stephanie: “Albanian Migration and New Transantionalisms", Journal of Ethnic and Racial Studies, vol. 29, nº 6 (2003), pp. 939-948.
} 
for immigrant groups and especially the so-called "other formations" have been strongest towards Albanian emigrants. However, Albanians who migrated together with northern Italians became partners because these groups were called "unwanted". In the historical process in Italy, the Northern Italians constituted the first "other formation" of their national identity. The economic and socio-cultural differences within Italy, created a national identity crisis. In addition, as a result of emigrants from Albania, Italians launched the Italian ethnos creating the sense of a strong nationality. ${ }^{40}$

Therefore, biased Italians pushed Albanians to change themselves by encouraging them in different ways by joining churches, changing their religion, etc. Until 1991, these people lived under the communist regime and couldn't find the power to stigmatizate their own national identity, but it is interesting that the same nation who lived under this pressure tried to create and develop their "community". ${ }^{41}$ Living under the autocratic pressure of the communism, in the post-communist period Italian culture played a key role in slowly changing the Albanian nation.

Historically, Greece's security depended on the stable environment created in the Balkans. The 1990s were the time of challenges for Greece. The process of disintegration of Yugoslavia reflected in the relations between Greece and Balkan countries. During this period, it was very difficult to provide a stable environment in the Balkans. The disintegration of Yugoslavia led to new problems for Greece, because the former Yugoslavia served as a buffer zone between the Balkan countries during the Warsaw Pact's period. This region also played a major role in the limitation of irredentism. ${ }^{42}$

In the south of Albania there is a Christian religious population. There is also an ethnic border that divides the regions inhabited by Muslims and Christians. Today the MuslimChristian dispute continues to arise. This problem underlies the causes of the First World War when Greeks destroyed Muslim villages and killed people that lived there. The Lausanne Treaty, signed in 1923 included a lot of items against Albanians. ${ }^{43}$ The Greek governments, counted the Orthodox Albanians (Arvanides) as Greek and didn't recognize the minority's ethnic and cultural rights. The teaching of Arvanitika language was not legally recognized by the Greek government and academic institutions. The Arvanides saw themselves as Orthodox Albanians. They wanted to establish their own churches but their request was not accepted by Greek government.

Greece started to improve the relations with its neighbors in the Balkans during the detent (1960) period. In 1970 the Greek military junta tried to reduce its neighbors' conflicts in the Balkans. In 1971 Greece and Albania re-launched their diplomatic relations.

During the post-communist era, people that were living in the Southern Albania crossed the Albanian-Greek border and began to use Christian names or use false documents

\footnotetext{
${ }^{40}$ Mai, Ibid., pp. 78.

${ }^{41}$ Mai, Ibid., pp. 79.

${ }^{42}$ Katsikas, Stefanos: “An Overview of Albania's Foreign Policy-Making in 1980s”, Slovo, , vol. 16, n 2 (Autumn 2004), pp. 91-96.

${ }^{43}$ Agani, Fehmi (1996): Pavaresia: Gjasa dhe Shprese, Paris, TOENA.
} 
about their identities presenting themselves as Greek nationals. ${ }^{44}$ A part of them also changed their religion. ${ }^{45}$

During the establishment of relations between Albania and Greece, the effect of the churches and the Greek schools was great. Until the First World War, in some Albanian village schools, lessons were totally taught in the Greek language. In addition, until 1966 the language spoken in churches was Greek. Education and religion were the guide for "national civilization" in Albania.

After the Greek Prime Minister Karamanlis, the Prime Minister Papandreou worked to continue the same policy of peace and cooperation in the region. Since the 1940s Papandreou adjourned the Greek territorial claims towards Albania. ${ }^{46}$ In 1990, faced with the Albanian nationalism in Macedonia and the Turkish efforts in the Balkans, Greece, concidered Serbia as its best ally. The populations of both countries was Orthodox and they engaged together in the Balkan and World Wars. In addition, both countries tried to prevent Turkish policy in the Balkans and they always feared Bulgaria's irredentism. ${ }^{47}$

In 1994, Greece experienced diplomatic isolationism especially towards the Balkan. This isolationism was focused against its Balkans neighbor, Serbia, and its Western ally the U.S. The Albanian government slowly began to revive the relations with Greece after establishing the so called political party, "Omonia 5". In March 1996 both countries signed the "Treaty of Friendship and Cooperation". 48

In 1999, Kosovo's war was a trial process for Simitis. Greek population became antiAmerican and pro-Serbian sentiments caused by the NATO's bombing in Serbia made Greece the most important contributer to Serbia's course for entering into the EU. On the contrary Kosovo is the most crucia obstacle to Serbia's membership to EU.

After containing the Kosovo crisis, tensions softened. But there are two issues that are still unresolved:

a- The Macedonian issue: In November 2004, FYROM was recognized by the EU as the Macedonia Republic which was protested by the Athens.

b- The Kosovo issue: Greece opted against Kosovo's independence, because according to the Greek policy this situation nourished the Albanian irredentist feelings and this would bring instability in Macedonia. In this regard, the U.S. remains impartial. In 1990 the United States, played an important role during Kosovo and Bosnia crisis. Greek-Turkish relations affect the issues in Balkans.

\footnotetext{
${ }^{44}$ Dimakos, Ioannis; Tasipoulou, Katerina: “Attitudes Towards Migrants: What Do Greek StudentsThink About Their Immigrant Classmates", Intercultural Education, vol. 14, nº 3 (2003), pp.307-316.

${ }^{45}$ Nicholson, Beryl: "The Wrong End of the Telescope: Economic Migrants, Immigration Policy, and How it Looks from Albania", Political Quarterly, vol. 73, no 4 (Oct.-Dec. 2002), pp. 436.

${ }^{46}$ Shea, John (1997): Macedonia and Greece: The Struggle to Define a New Balkan Nation, London.

${ }^{47}$ R. King, Robert (1973): Minorities Under Communist, Massachusetts, Harvard University Press.

${ }^{48}$ Rougheri, Christina: Traditional Greek Nationalism Breeds New Display of Intolerance, at www.aimpress.org.
} 


\subsection{The Albanian Europeanization and European Union Factor}

Albania is in a strategic location. For this reason, it is always considered a potential rival. Therefore, Albania is directed to explore other ways for her security. Albania became a member of PfP and OSCE. On April 3, 2008, Albania received the NATO membership invitation. At the beginning of 1980s, the Albanian President, Ramiz Alia, said "Albania is a European country which is why she is interested in everything about this continent". ${ }^{49}$ In this regard Albania overrated her relations with the EU and has always made efforts to expand these relations steadily. EU-Albania relations first began in 1991. From this time the EU has been an effective supporter of Albania the country continued to make reforms in institutional, political and economic areas. ${ }^{50}$

In May 1991, the EU adopted a new initiative for the five Balkan countries: Albania, Macedonia, Croatia, Bosnia-Herzegovina and the Federal Republic of Yugoslavia. This initiative was called "The Stabilisation and Association Process". This process aimed at the develpment of the relations between Balkan countries and the EU. It helped the countries also to go through the "Stabilisation and Association Agreement". In November 1999 the EU Commission report claimed that Albania did not fulfill the required criteria to sign such an agreement because, according to the "Feasibility Analysis" done in Albania, the results were not viable. ${ }^{51}$ The EU Council met in June 2000 to discuss the future of the Western Balkan states stating that the countries for the "Stabilisation and Association Process" were all potential candidates for EU membership.

In November 2000,the members ofthe "Stabilization and Association Process" participated in a meeting in Zagreb. At this meeting the EU decided to develop its cooperation with Albania. For this reason, the EU-Albania High Level Steering Group was created. The aim of this group was to handle the evaluation of the progress of Albania's obligations to the EU Accession Treaty. The EU-Albania High Level Steering Group in Tirana held a few meetings and prepared a report indicating the progreses and the areas of improvements that ought to be made. With the assessment of this report the EU Commission concluded that Albania needed to make some more reforms regarding the "Stability and Association Agreement". Meanwhile, the EU decided that this time was oportune begin the negotiations for this agreement. ${ }^{52}$

In December 2001, the EU Commission presented a draft mandate to the EU Council for the starting of the negotiations of the "Stabilisation and Association Agreement" between the EU and Albania. At the same time it was decided that the EU-Albania Consulting Group be created. With the proxy proposal given for the starting of the agreement, by the EU Council from January to July 2002 and it was decided to begin negotiations with Albania on 31 January 2002. On January 31, 2003 the EU Council President, Romano Prodi, declared the start of the negotiations. ${ }^{53}$ Albania needed to comply and agree with the Copenhagen Summit's (December 2002) in regards to economic and political criteria to be part of the

\footnotetext{
${ }^{49}$ Albania, at http//: www.state.gov/www/background_notes/albania_9903_bgn.html\#foreign.

${ }^{50}$ Bogdani, Mirela (2003): Shqiperia dhe Bashkimi Europian: Integrimi Evropian dhe Perspektiva e Pranimit, Tirane.

51 "Shqiperia dhe BE: Marreveshja e Stabilizim-Asocimit”, Report $n^{\circ} 2$ (2004), at http://www.aeuric.org/integrimi.html.

${ }^{52}$ Albania, at http//: www.state.gov/www/background_notes/albania_9903_bgn.html\#foreign.

${ }^{53}$ Trimçev, Eno (2006), Shqiperia dhe BE: Perceptime dhe Realitete 2006, Tirane.
} 
"Stabilisation and Association Agreement". Finally, the integration of the candidate countries to EU will be under the obligation to comply with the acquis communautaire. The "Stabilisation and Association Agreement" is based on three pillars:
a- Political and regional cooperation
b- The establishment of the Free Trade Zone between the parties
c- Cooperation on issues like justice and internal affairs.

These meetings included an interval of about six weeks and the issues were of political and technical in nature. The intensity of these meetings made it possible for this agreement to be signed in mid 2006. As underlined in the Zagreb Summit (2000), the "Stabilisation and Association Process" is not only a bilateral process, but it is also an important process for regional cooperation. This is seen clearer in the agenda of the regional financial aid programs such as CARDS. ${ }^{54}$

The Thessaloniki Summit of June, 21, 2003 was an important step for the development of the EU and Western Balkan countries relations. In this summit the issues that supported concrete ways that would bring together EU and Western Balkan countries were highlighted. Particularly, the progress of the Western Balkan countries towards the EU membership was to be based on their performance, measures and successes in the area of economic reforms, democratic standards and human and minority rights maintenance. ${ }^{55}$

There were two messages to be taken from the Thessaloniki Summit:

a- The map of the EU shall not be considered complete without the Balkan countries. The EU shall provide every kind of aid for the development of these countries.

b- Meanwhile, EU membership will only be acquired after intensive work and political will of the politicians of the Balkans region.

Balkan countries are supported by the EU and the South-East Europe Stability Pact and are trying to create a single Free Trade Area. This process is the product of the idea of expansion of the Central Europe Free Trade Area (CEFTA).

It is important to notice that a decline in public revenues will be felt with the removal of customs tariffs. For filling the gap created by this situation, the concerned Balkan states must reform the countries' production and marketing sectors. Thus, the preparation of the Balkan countries before joining the European Union will be helpful in order to avoid fierce commercial competition. The EU Commission assumed that establishing the Free Trade Zone in the Balkans was an opportunity that would strengthen the experiences because it was a process that prepares these countries for the EU membership.

\footnotetext{
${ }^{54}$ Bogdani, op. cit., p. 59.

${ }^{55}$ Ibid., p. 65.
} 
Recently, the EU has been closely monitoring the reform process in the Balkans on the one hand, but on the other hand the skepticism created from the growing wave of the new enlargements impedes the quick progress of the reforms. Therefore, the Western Balkan countries fear the possibility of the EU's policy towards them as it could cause a spontaneosly negative change and these countries would not fullfill the commitments concerning the EU. In other words, all countries in the region are trying to gain entrance to the EU as soon as possible from "the ill Balkans" before the doors are closed.

\subsection{Albanian Foreign Policy and the Role of the United States}

Successive U.S. Administrations have expressed strong support for Albania's political and economic transition and its Euro-Atlantic integration aspirations, including membership in NATO. Until March 15, 1991 there was not significant diplomatic relation between Albania and the United States. ${ }^{56}$ By the end of the Cold War Albania established and developed its international relations in the international arena. This differentiated policy relationships had different dimensions:

a- Albania evolved from the communism to the democratic regime.

b- By the end of the Cold War and the disintegration of former Yugoslavia, the "Albanian Question" became more dynamic than it was before. In this respect, the United States appeared to be the strategic partner of Albania.

c- Geopolitically the establishment of Albania-US relations positively affected the region. ${ }^{57}$ After the creation of Berisha's Government (1991), Albania's foreign policy and its democratization process were supported by U.S. In the early 1990s there was most likely no other European country that had the same will as Albania for the creation of good relations with U.S. ${ }^{58}$

It is true that Washington affected the moderation of Albania's policy in the Balkans. ${ }^{59}$ Albania is considered to be a constructive partner in promoting regional stability in the Balkans, a key U.S. objective in Europe that has regained prominence as the international community prepares to address the issue of Kosovo's future political status before 2007. In other words, aside from the advantages that Washington had over Albania's ports, it has been one of the main international actors playing an important role in Albanian foreign policy. In 1995, the U.S. President invited Berisha to Washington. At this meeting between Berisha and Clinton, Tirana's importance in the Balkans region was emphasised along US-Albania relations. Clinton congratulated the responsible approach of Berisha towards the ethnic Albanians in the Former Yugoslavia for the supportion of Kosovo's autonomy. During this visit, Berisha proposed to the U.S. government the use of the military bases in Albania. The leader of the Albanian Socialist Party, Pellumbi, criticized Berisha describing this propasal as "irresponsibility" as it was an action that does not respect and protect the Albanian national

\footnotetext{
56 Tindemans, Leo (1997): Barışa Çă̆rı: Uluslararası Komisyon'un Balkanlar Hakkındaki Raporu, Istanbul, Sabah Yayınları.

${ }^{57}$ Papa, Robert (2004): Diplomacia Amerikane dhe Shqiperia, Tirane, Dituria.

${ }^{58}$ Biberaj, op. cit., p. 232.

${ }^{59}$ Tindemans, op. cit., pp. 156.
} 
interests. But these relations between Albania and U.S. had a good reflection for the Albanian national question. It was seen in March 1998 when the U.S. military powers partook in Kosovo's war. The Kosovo question didn't only affect the United States' Balkan policy, but also the changes it brought in the structure of the international system. The U.S. intervention to Kosovo without any decision of the UN Security Council is concidered as an direct intervention to the internal affairs of a country. This was the first time that UN intervened in this manner. ${ }^{60}$

Not even the U.S. played a positive role in solving Albania's national question but Albania also played an active role in the U.S. missions. The Bush Administration has lauded Albania's cooperation in the war on terrorism and its contributions to U.S. led operations in Iraq and Afghanistan. Albania also offered the United States access to its airspace, land routes, and territorial waters in support of these operations. Albania has established a bilateral agreement with the United States on exempting U.S. personnel from possible extradition to the International Criminal Court (ICC, a so-called "Article 98" agreement), and another agreement on the Prevention of Proliferation of Weapons of Mass Destruction.

As noted before, Albania's bilateral assistance aside from that of the Western European states and international organizations is provided by United States as well. The good thing is that Albania is very receptive to EU-U.S. guidance. That notwithstanding, of all of the elections held in post-communist Albania, not a single one of them has been in full accordance with "European" standards. Nevertheless, the international community (OSCE and so forth) always accept the results in Albania. This in itself brings to mind the question of legitimacy. For the sake of stability, the EU and U.S. have approved all the previous results, but this poses a burden on democratic reforms in Albania. The EU and U.S. need to be clear and concise on what they want from the Albanian political leadership and compel the two sides to sit at the negotiation table for compromise because there is no more time left to delay an European-Albanian's future. ${ }^{61}$

\subsection{Relations with Islamic Countries and Turkev}

Albania has established warm relations with the Islamic countries. In August 1992, the Emir of Kuwait visited Tirana. In 1992, Albania joined the Islamic Conference as an observer in Saudi Arabia. Albania also receives aid from many Islamic countries. However, Sali Berisha was criticized by Western countries because Tirana's good relations with Islamic countries affected negatively Albanian relations with the West. The Albanian government responded to these criticisms specifying that the aim of the government is to establish relations at the highest level possible with all countries.

The Albanian Foreign Affairs Minister, A. Serreqi, participated in the Islamic Conference. In his speech he stressed that $70 \%$ of the Albanian Muslim population is an important factor in the Albania's relations with Islamic countries. In economic terms, these potential countries support the Albanian government financially.

In 1992, with the democratization of Albania, the relations with the Islamic world and especially with Turkey received high priority. Turkey's government also gives importance to the relations the country has with Albania. The Turkish-Albanian close relations are due to

\footnotetext{
${ }^{60}$ Biberaj,op. cit., pp.233.

${ }^{61}$ Albania: The Wider Implications of a Political Crisis-Turned Violent, at

http://www.isaintel.com/2011/02/07/albania-the-wider-implications-of-a-political-crisis-turned-violent/
} 
their similar history and culture. Therefore, after 1992 Albania became the second secular country with a Muslim majority that was ruled by a democratic regime. Besides this, in many different Balkan countries there are some Albanian minorities that contribute to a better dialogue between Turkey and the countries they are living. The end of the Cold War, with the disappearance of the Soviet Union and Yugoslavia (1990) brought challenges and opportunities to regional and global powers. The emergence of the liberal democracies in most of the Balkan countries created a buffer zone between Europe and Turkey. Turkey found itself at the center of the changing geopolitics in the region of the Balkans. ${ }^{62}$ Turkey mended its efforts to reinforce the Balkan countries institutions and the building of their economic welfare.

Albania needs to cooperate more systematically with Turkey. The gaps between Albanian-Turkish relations consist of:

- After the agreements reached between Turkey and Albania they couldn't develop a good coordination.

- After making decisions, they didn't follow the application of a systematic style.

- Between these countries no tactical agreements have been reached.

After the September 11th attacks Turkey has been involved in the Balkan region and is trying to make a significant contribution supporting the states. Abandoning the learned experiences from the past, AKP is wrapped in concepts such as 'strategic depth', 'pro activism', 'zero problem with neighbours', 'geographical centralism' and 'soft balancing'. In other words, Turkey`s new foreign policy has converted in a populist policy that means that Turkey will be an omnipresent and an omnipotent country towards different geographies and without doubt towards Albania. Therefore, fiven Turkey's location, the existing cultural and historical ties with the region and especially the Muslim people (because of their ownership of the assets), is necessary in adjusting its position if the power balances will change.

\section{Conclusions}

"If states pursue only their rational self-interests, without defining them they will collide with other states only minimally." ${ }^{63}$ National security is the first objective necessary before any other policy objectives like prosperity, national honour or cultural enrichment can be pursued. In this view today's Balkans region security is complicated because there are a lot of dynamisms that are nourishing this situation. Furthermore, with the enlargement of NATO, as a source of security, the Balkans in these conflicts seem to be limited. In this respect, if Albania continues to fulfill the criterias in becoming a member of the EU, bilateral and international relations be strengthened. Since the collapse of communism, the policy agenda of Albanian political elites has been strongly influenced by the desire to join international organizations. Following a long period of extreme isolation, membership in these organizations would offer Albania a new place in the international arena.

\footnotetext{
${ }^{62}$ Soyasal, Mümtaz: “The Future of Turkish Foreign Policy”, in Martin, L.G. and Keridis, Dimitris (eds.) (2004): BCSIA Studies in International Security, Cambridge, The MIT Press, pp. 353-354.

${ }^{63}$ Morgenthau, Hans J. (1962): The Impasse of American Foreign Policy, Chicago, The University of Chicago Press.
} 
In April 2008, Albania received an invitation for membership from the North Atlantic Alliance. This was of a great importance in Albanian history because:

- Albania became politically closer to the Western World. Albania, as a NATO member, won back its Western identity. Tirana de facto was included to the NATO security structure by contributing to the tasks undertaken. Consequently, this is the evidence that Albania will play an important role as an active member in stabilizating any instability that may occur in the future.

- There are a number of minority groups in different countries of the Balkans. Most of time, these groups jeopardize peace and stability. In this respect, it seems that Albania poses a security threat in the Balkan region. The Western Balkan countries consider the country indispensable ally to the NATO membership to ensure the security in the region. If in the future any instability occurs in Balkans region Albania's contribution to security as a NATO member, will translate into responsibility to Balkan peace.

- There are a large number of Albanian minorities living in the Balkans region. This is a positive factor and a major political force in terms of the bilateral relations that Albania has with these countries. In this respect, it can be concluded that the problems that exist between the Balkan countries will change into the desire for confidencebuilding between all the countries. This will follow the security of the enlarged Europe or Adriatic-Black Sea-Caspian Sea region policies. In this respect, the Eastern Adriatic region of the Western Balkans, should enter into the EU and NATO as soon as possible.

- Albanians are living in several Balkan countries. The Albanian government's policy towards the Albanians that are living in these regions has been/will be in the direction of ensuring peace, security and economic cooperation in the whole region. In this view, FYROM in the Brussels Summit held on April, 2008 didn't receive an invitation for NATO membership. This increases the Albania's responsibilities in the Balkans. Accountability, in Albania was also avoided during the ethnic and religious conflicts and this provided a historical advantage for Tirana.

- With the enlargement of Euro-Atlantic structures, Albania will gain the opportunity to re-win the Albanian minorities spread all over the Balkan countries. In other words, the new enlargements will pave the paths of winning the Albanian minorities in the Balkans. Albania, adhering to the same structures with Greece, will together ensure with the countries security and will resolve the problems they have today. The Albanian Government will play a mediator role between Greece and FYROM for the dispute they have about the name. So rather than creating a "Greater Albania", Tirana with her foreign policy, is trying to slow down the volatile disputes that Albanian minorities have created in the Balkan region.

However, noticing today's political situation in Albania, Albania's NATO membership is not the end of the path to its progress towards Euro-Atlantic integration. Political elites in Albania supported the NATO and EU policies of conditionality as they believed that Western democracy was the only and best choice for Albania. Albania's EU accession process is a political project not yet completed. The post-communist Albanian elites declared "return to Europe" as their first foreign policy priority. On the other hand, in Albania the state was 
extremely weak and thus fell prey to both external and internal processes beyond its control. Therefore, they increasingly focused their efforts on satisfying the requirements of accession to the main Euro-Atlantic international organizations, and regardless of the diverse methods, instruments and resources international organizations use, they share the same objective: to help promote democracy, stability and security. In other words, international organizations have shaped domestic and international politics in Albania. In this view the Albanian political class should continue to construct a stable democracy based on European standards, consolidate democratic institutions, ensure economic growth, conduct elections in full compliance with international standards, develop civil society, fight against corruption and organized crime, ensure independence for the judiciary and attract more foreign investments. This is the only way to strengthen the Albanian international position and activate its role in Balkans region.

\section{Referentes}

Agron Alibali, Mendime per Çeshtjen kombetare Shqiptare dhe Disa Probleme te se Drejtes Kombetare, 1997.

Albert Doja, Perdorimi Politik i Fese ne Rindertimin e Identiteteve, Rasti Shqiptar, Tirane, 2001.

Alexandra Popovic, Balkanlar'da İslam, Istanbul, 1995.

Alexis de Tocqueville, Democracy in America, trans. Henry Reeve 2 vols., 1840; rpr. New York, 1961.

B. Qorri, Shqiperia e Vertete, Tirane, 1944.

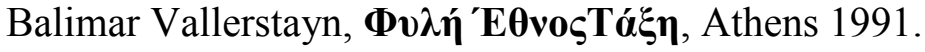

Beqir Meta, Tensioni Greko-Shqiptar: 1939-1949, Shtepia Botuese Geer, Tirane, 2002.

Beryl Nicholson, "The Wrong End of the Telescope: Economic Migrants, Immigration

Policy, and How it Looks from Albania", Political Quarterly, Vol. 73, Issue 4, Oct.-Dec. 2002 .

Christina Rougheri, "Traditional Greek Nationalism Breeds New Display of Intolerance", Alternative Information Network (AIM), Athens, 24.06.1998.

Debie F., "Greece, Italy and Europe In the Fce of The Albanian Problem ", in : Levy , J., Ed., From Geopolitics to Global Politics, London/Portland, 2001.

Eno Trimçev, Shqiperia dhe BE: Perceptime dhe Realitete 2006, Tirane, 2006.

Erjada Progonati, "The Albanian Minorities on Albanian Foreign Policy: Kosovo, Greece, Macedonia", (Unpublished) Master of Arts in International Relations Thesis, The Institute of Social Sciences of Gazi University, Ankara, 2008.

Erhan Türbedar, Stratejik Öngörü: Balkanlar 2006, ASAM 2006. 
Erhan Türbedar, "Tedirginlikten Dostluğa: Yunanistan-Arnavutluk İlişkileri”, Stratejik Analiz, November 2007.

Fehmi Agani, Pavaresia: Gjasa dhe Shprese, Paris, 1996.

Ferrucio Pastore, "Conflicts and Migrations: A case Study on Albania", Briefing for the

Conflict Prevention Network of the EC, Revised Version Jan. 1998, Available at: Albanian

Emigration and Greek Labour Market: Economic Symbiosis and Social Ambiguity, 1/2004

South-East Europe Review 65, http://www.cespi.it/PASTORE/Albania1998.PDF

Georgi Tsekov, "Sons of the Eagle: Clan Warfare Organized Crime and State Disintegration in the Western Balkans”, Southeast European and Black Sea Studies, Vol. 2, No. 3, 2002. Ioannis Dimakos; Katerina Tasipoulou, “Attitudes Towards Migrants: What Do Greek StudentsThink About Their Immigrant Classmates", Intercultural Education, Vol. 14, No. 3, 2003.

John Shea, Macedonia and Greece: The Struggle to Define a New Balkan Nation, London 1997.

King Russell; Nicola Mai, "Of Myths and Mirrors: Interpretations of Albanian Migration to Italy", Studi Emigrazione,Vol. 145, 2002.

Leo Tindemans, Barışa Çağrı: Uluslararası Komisyon’un Balkanlar Hakkındaki Raporu, İstanbul: Sabah Yayınları, 1997.

Mirela Bogdani, Shqiperia dhe Bashkimi Europian: Integrimi Evropian dhe Perspektiva e Pranimit, Tirane, 2003.

Mirlinda Çelmeta, E Drejta per Vetevendosje e Shqiptareve te Kosoves, Shtepia Botuese Flesh, Tirane 2001

Morgenthau, In Defence of the National Interest, New York: Alfred A. Knopf, 1951.

Morgenthau, The Impasse of American Foreign Policy, The University of Chicago Press, Chicago, 1962.

Mümtaz Soyasal, "The Future of Turkish Foreign Policy,” The Future of Turkish Foreign Policy, ed. L.G. Martin \& Dimitris Keridis, Cambridge: The MIT Press, 2004.

Nafiz Mandacı, Birsen Erdoğan, "Balkanlar'da Azınlık Sorunu: Yunanistan, Arnavutluk, Makedonya ve Bulgaristan'daki Azınlıklara bir Bakış", SAEMK, Ankara, 2001.

Naz Çavuşoğlu, Uluslararası İnsan Hakları Hukukunda Azınlık Hakları, Su Yayınları, Ankara, April 2001. 
Nicola Mai, "The Cultural Construction of Italy in Albania and Vica Versa: Migration Dynamics, Strategies of Resistance and Politics of Mutual Self-Definition Across Colonialism and Post-Colonialism”, Modern Italy, Vol. 8, Issue 1, May 2003.

Nicola Mai; Stephanie Schwander-Sievers, "Albanian Migration and New

Transantionalisms”, Journal of Ethnic and Racial Studies, Vol. 29, No. 6, 2003.

Ortakovski V. T., "Greater Serbian, Greater Albanian Nationalism and Kosovo”, Paper

Presented at the Annual Meeting of the International Studies Associaotion 48th Annual

Convetion, Hilton Chicago, IL, USA Online PDF from

http://allacademic.com/meta/p178655 index.html.

“Pan-Albanism: How Big a Threat to Balkan Stability?", ICG Europe Report, No. 153, 25

February 2004.

Remzi Lani, Fabian Schmidt, "Albanian Foreign Policy Between Geography and History",

The International Spectator, Cilt 33, Say1: No.2, April-June 1998.

Robert Papa, Diplomacia Amerikane dhe Shqiperia, Tirane, 2004.

Robert R. King, Minorities Under Communism, Harvard University Press, Cambridge, Massachusetts, 1973.

Rozeta E. Shembliku, "The National Interest Tradition and the Foreign Policy of Albania”, Master of Arts Thesis, 2004.

Terence Duffy, "Albania: Beyonce The Hoxha Legacy", Transformations of PostCommunsits States, Londra, Macmillan Press Ltd, 2000.

Thanos Veremis, Greece's Balkan Entanglement, Athens, 1995.

Stefanos Katsikas, "An Overview of Albania's Foreign Policy-Making in 1980s”, Slovo, Vol. 16, Issue 2, 2004.

Süleyman Sırrı Terzioğlu, Uluslararası Hukukta Azınlıklar ve Anadilde Eğitim Hakkı, Alp Yayınevi, Ankara, May 2007.

Veli Yılmaz, Siyasi Tarih, İstanbul, Harp Akademileri Basım Evi, 1998.

Stabilization and Asociation Report, 2008.

Yunanistan'da Etnik Gruplar ve Azınlıklar, Ankara, 1999.

Materiale mbi Epirin dhe "Vorio Epirin", 1977, The archive of Albanian Foreign Policy Ministry, Dosya 1135.

"Politika Ballkanike e Greqise Sot", "Koha Jone" Journal, (15.02.2008).

http//: www.state.gov/www/background_notes/albania_9903_bgn.html\#foreign, (15.09.2010).

Report No.2, Shqiperia dhe BE: Marreveshja e Stabilizim-Asocimit, 2004.

http//:www.state.gov/www/background_notes/albania_9903_bgn.html\#foreign,(16) 